\title{
Expression of chemokine receptors on peripheral blood lymphocytes in multiple sclerosis and neuromyelitis optica
}

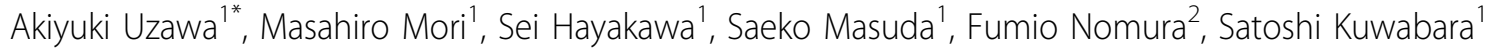

\begin{abstract}
Background: The role of different chemokine receptors in the pathogenesis of multiple sclerosis (MS) has been extensively investigated; however, little is known about the difference in the role of chemokine receptors between the pathogenesis of neuromyelitis optica (NMO) and MS. Therefore, we examined the expression of chemokine receptors on peripheral blood lymphocytes (PBL) in MS and NMO.

Methods: We used flow cytometry to analyse lymphocyte subsets in 12 patients with relapsing NMO, 24 with relapsing-remitting MS during relapse, 3 with $\mathrm{NMO}$ and 5 with MS during remission.

Results: Compared with healthy controls $(\mathrm{HC})$, the percentage of lymphocytes in white blood cells was significantly lower in $\mathrm{NMO}$ and MS patients. The percentage of T cells expressing $\mathrm{CD} 4{ }^{+} \mathrm{CD} 25^{+}$and $\mathrm{CD} 4^{+} \mathrm{CD} 45 \mathrm{RO}^{+}$was higher, while that of $C D 4^{+} C C$ chemokine receptor (CCR) $3^{+}$(T helper 2, Th2) was significantly lower in MS patients than in $\mathrm{HC}$. The ratios of $\mathrm{CD}^{+} \mathrm{CXC}$ chemokine receptors (CXCR) $3^{+} / \mathrm{CD} 4^{+} \mathrm{CCR} 3^{+}$(Th1/Th2) and $\mathrm{CD} 8^{+} \mathrm{CXCR} 3^{+} / \mathrm{CD} 8^{+} \mathrm{CCR} 4^{+}$(T cytotoxic 1 , $\mathrm{Tc} 1 / \mathrm{TC} 2)$ were higher in MS patients than in $\mathrm{HC}$. The percentage of $\mathrm{CD} 8^{+} \mathrm{CXCR3^{+ }} \mathrm{T}$ cell $(\mathrm{Tc} 1)$ and $\mathrm{CD} 4^{+} \mathrm{CXCR3}{ }^{+} \mathrm{T}$ cell (Th1) decreased significantly during remission in MS patients $(P<0.05)$. No significant differences were identified in the expression of the chemokine receptors on PBL in NMO patients compared with MS patients and HC.

Conclusions: Th1 dominance of chemokine receptors on blood T cells and the correlation between CXCR3 ${ }^{+} \mathrm{T}$ cell (Th1 and TC1) and disease activity in MS patients were confirmed by analysing chemokines receptors on PBL. In contrast, deviation in the Th1/Th2 balance was not observed in NMO patients.
\end{abstract}

\section{Background}

Chemokines attract various types of leukocytes to sites of infection and inflammation and act as immunoregulatory molecules in driving $\mathrm{T}$-helper $(\mathrm{Th}) 1 / \mathrm{Th} 2$ responses [1]. The role of different chemokines and chemokine receptors in the pathogenesis of multiple sclerosis (MS) has been extensively investigated [2-5]; however, little is known about the role of chemokine receptors in the pathogenesis of neuromyelitis optica (NMO).

$\mathrm{NMO}$ is an immune-mediated inflammatory disorder of the central nervous system and predominantly affects the optic nerves and spinal cord [6]. Recent evidences such as the discovery of serum anti-aquaporin-4 (AQP4) antibody in NMO patients [7] (now recognised as a specific

\footnotetext{
* Correspondence: a-uzimp1204@graduate.chiba-u.jp

'Department of Neurology Graduate School of Medicine, Chiba University,

Chiba, Japan

Full list of author information is available at the end of the article
}

biomarker for NMO), differences in pathology [8], neuroimaging [9], cytokine profiles [10,11] and responses to some immunotherapies between MS and NMO [12], supports the hypothesis that NMO is distinct from MS.

In the present study, we report the expression of chemokine receptors on peripheral blood lymphocytes (PBL) in NMO and MS during relapse compared with healthy controls $(\mathrm{HC})$ to determine differences in the expression of chemokine receptors between these disorders.

\section{Methods \\ Patients}

This study included 12 Japanese patients with relapsing NMO fulfilling Wingerchuk's revised criteria [6] that uses seropositivity of the anti-AQP4 antibody [13] instead of NMO-IgG. In addition, the study included 24 patients with relapsing-remitting MS fulfilling 
McDonald's criteria [14]. Their whole blood samples were obtained during relapse, which was defined as the period within one month of clinical relapse and before beginning relapse treatment. Blood samples from 25 healthy participants ( 9 women and 16 men; mean age, 32.7 years) served as controls. In addition, blood samples during remission were obtained from only 3 of the $12 \mathrm{NMO}$ patients and 5 of the $24 \mathrm{MS}$ patients.

We also reviewed the clinical characteristics of NMO and MS patients such as gender, age, disease duration, expanded disability status scale (EDSS) and the proportion of patients receiving immunomodulating treatment.

Ethics approval was granted by the Ethics Committee of Chiba University School of Medicine, Chiba, Japan. All study subjects gave informed consent for their participation.

\section{Flow cytometry}

Blood samples collected in heparinised tubes were washed with phosphate buffered saline (PBS), supplemented with $0.5 \%$ foetal calf serum and resuspended in PBS with $0.5 \%$ foetal calf serum. Subsequently, the aliquots of the cell suspensions were double-stained with fluorescein isothiocyanate- and phycoerythrin-labelled monoclonal antibodies for $30 \mathrm{~min}$ at $4{ }^{\circ} \mathrm{C}$ in the dark. Table 1 summarises the combinations of monoclonal antibodies used to identify chemokine receptor-positive cells as well as for other lymphocyte subsets. After lysing the red blood cells with FACS Lysing Solution (BD Biosciences, San Jose, CA, USA.), the cells were washed with PBS and resuspended in $0.5 \mathrm{ml}$ PBS. IgG1 coupled to fluorescein isothiocyanate and IgG2a coupled to phycoerythrin were used as negative controls. The percentages of chemokine receptor-positive cells or lymphocyte subsets were obtained using a FACScan (BD Biosciences).

\section{Statistical analysis}

For baseline variables, the groups were compared using Fisher's exact test for categorical outcomes, the MannWhitney $U$ test for continuous variables and paired

\section{Table 1 Combinations of monoclonal antibodies used}

\begin{tabular}{|c|c|}
\hline Chemokine receptor-positive cells & Other lymphocyte subsets \\
\hline FITC-labelled PE-labelled & FITC-labelled PE-labelled \\
\hline $\mathrm{CCR}^{\mathrm{C}} \times \mathrm{CD}^{\mathrm{b}}$ & $\mathrm{CD}^{\mathrm{a}} \times \mathrm{CD} 1^{\mathrm{a}}$ \\
\hline $\mathrm{CD} 4^{\mathrm{b}} \times \mathrm{CCR}^{\mathrm{a}}$ & $\mathrm{CD}^{\mathrm{a}} \times \mathrm{CD}^{\mathrm{a}}$ \\
\hline $\mathrm{CCR}^{\mathrm{c}} \times \mathrm{CD}^{\mathrm{b}}$ & $\mathrm{CD}^{\mathrm{a}} \times \mathrm{CD}^{\mathrm{a}}$ \\
\hline $\mathrm{CXCR} 3^{\mathrm{c}} \times \mathrm{CD}^{\mathrm{b}}$ & $\mathrm{CD} 4^{\mathrm{b}} \times \mathrm{CD} 25^{\mathrm{a}}$ \\
\hline $\mathrm{CD} 8^{\mathrm{b}} \times \mathrm{CCR}^{\mathrm{a}}$ & $C D 45 R A^{a} \times C D 4^{b}$ \\
\hline $\mathrm{CXCR}^{\mathrm{c}} \times \mathrm{CD}^{\mathrm{b}}$ & $\mathrm{CD} 4^{\mathrm{b}} \times \mathrm{CD} 45 \mathrm{RO}^{\mathrm{a}}$ \\
\hline
\end{tabular}

Monoclonal antibodies were purchased from ${ }^{\mathrm{a}} \mathrm{BD}$ Biosciences, San Jose, $\mathrm{CA}$, USA, ${ }^{\mathrm{B}}$ Beckman Coulter, Marseille, France, or ${ }^{\mathrm{C} D a k o}$ Japan, Kyoto, Japan, FITC = fluorescein isothiocyanate; $\mathrm{PE}=$ phycoerythrin; $\mathrm{CCR}=\mathrm{CC}$ chemokine receptor; $\mathrm{CXCR}=\mathrm{CXC}$ chemokine receptor. t-test for paired continuous measures. All comparisons were planned, tests were two-sided and $P$ values $<0.05$ were considered to be statistically significant. In addition, multiple testing problems were resolved by applying the Bonferroni correction on the computed $P$ values to reduce type I errors. All statistical analyses were performed using SPSS 16.0J (SPSS Japan Inc., Tokyo, Japan).

\section{Results}

\section{Clinical characteristics of NMO and MS patients}

Clinical characteristics of $12 \mathrm{NMO}$ and 24 MS patients are as described below. The proportion of female patients $(\mathrm{NMO}$, men:women $=0: 12$;S, men:women $=5: 19 ; P=$ 0.11 ), age (NMO, $48.3 \pm 13.8$ years old [mean \pm SD]; MS, $33.9 \pm 10.0 ; P=0.04$ ) and EDSS (NMO, 8.0 [range 2.09.0]; MS, 3.0 [1.5-7.5]; $P<0.001)$ at the blood sampling were higher in NMO than in MS patients. The proportion of patients who received immunomodulating therapy was not statistically different between $\mathrm{NMO}$ and MS patients (33\% in NMO, 1 patient with interferon beta and 3 with oral prednisolone; $21 \%$ in MS, 4 patients with interferon beta and 1 with oral prednisolone).

\section{Lymphocytes subsets in NMO and MS patients}

White blood cell $($ WBC) counts were $7352 \pm 732 / \mu \mathrm{l}$ (mean \pm SE), $7492 \pm 513$ and $5864 \pm 274$ in MS patients, NMO patients and $\mathrm{HC}$, respectively. WBC counts were significantly elevated in NMO and MS patients than in HC. Compared to HC, the percentage of lymphocytes was significantly lower in both NMO and MS patients. The percentage of $\mathrm{T}$ cells expressing $\mathrm{CD} 4{ }^{+} \mathrm{CD} 25^{+}$and $\mathrm{CD} 4{ }^{+} \mathrm{CD} 45 \mathrm{RO}^{+}$was significantly higher, while the percentage of $\mathrm{T}$ cells expressing $\mathrm{CD} 4{ }^{+} \mathrm{CC}$ chemokine receptor (CCR) $3^{+}$(Th2 cells) was significantly lower in MS patients than in HC. The ratios of $\mathrm{CD} 4^{+} \mathrm{CXC}$ chemokine receptors (CXCR) $3^{+} / \mathrm{CD}{ }^{+} \mathrm{CCR}^{+}{ }^{+}$indicating Th1/Th2 and $\mathrm{CD} 8^{+} \mathrm{CXCR}^{+} /$ $\mathrm{CD}^{+}{ }^{+} \mathrm{CCR} 4^{+}$indicating cytotoxic $\mathrm{T}(\mathrm{Tc}) 1 / \mathrm{Tc} 2$ was significantly higher only in MS patients. Although not statistically significant after applying the Bonferroni correction, the percentages of $\mathrm{CD} 4^{+} \mathrm{CXCR} 3^{+} \mathrm{T}$ cells (Th1 cells; $P=0.039$ ), $\mathrm{CD}^{+} \mathrm{CXCR}^{+}{ }^{+} \mathrm{T}$ cells $(\mathrm{Tc} 1$ cells; $P=0.020)$ and the ratio of $\mathrm{CD} 4^{+} \mathrm{CXCR}^{+} / \mathrm{CD} 4^{+} \mathrm{CCR} 4^{+}$ indicating Th1/Th2 $(P=0.023)$ tended to be higher in MS patients compared with HC. CD $8^{+} \mathrm{CCR} 4^{+} \mathrm{T}$ cells (Tc2 cells; $P=0.017$ ) and the ratio of $\mathrm{CD} 4^{+} \mathrm{CCR} 5^{+} /-$ $\mathrm{CD} 4^{+} \mathrm{CCR} 4^{+}$indicating Th1/Th2 $(P=0.041)$ tended to be lower in MS patients than in HC (Table 2). After applying the Bonferroni correction, NMO patients did not show any significant differences in the expression of the chemokine receptors on PBL compared with MS patients and $\mathrm{HC}$. The analysis of patients between the relapse and remission phases revealed significantly 
Table 2 Lymphocyte subsets (\%) on blood of patients with NMO and MS

\begin{tabular}{|c|c|c|c|c|c|c|c|}
\hline \multirow[t]{2}{*}{ PB measurements (\%) } & \multirow[t]{2}{*}{ Lymphocyte subsets } & \multirow[t]{2}{*}{ NMO $(n=12)$} & \multirow[t]{2}{*}{ MS $(n=24)$} & \multirow[t]{2}{*}{ NC $(n=25)$} & \multicolumn{3}{|l|}{$P$ value } \\
\hline & & & & & NMO vs NC & MS vs NC & NMO vs MS \\
\hline Lymphocyte & & $18.8 \pm 1.8$ & $25.7 \pm 2.0$ & $35.4 \pm 1.8$ & $<0.001^{*}$ & $0.001^{*}$ & $0.009^{*}$ \\
\hline CD3+ & T cell & $73.5 \pm 2.6$ & $70.2 \pm 1.7$ & $66.1 \pm 1.7$ & 0.039 & 0.071 & 0.486 \\
\hline $\mathrm{CD} 3+\mathrm{CD} 4+$ & $\mathrm{Th} / \mathrm{Ti}$ & $40.8 \pm 2.9$ & $41.6 \pm 2.2$ & $38.8 \pm 1.3$ & 0.212 & 0.045 & 0.837 \\
\hline $\mathrm{CD} 3+\mathrm{CD} 8+$ & $\mathrm{Ts} / \mathrm{Tc}$ & $31.5 \pm 2.7$ & $28.4 \pm 1.7$ & $26.4 \pm 1.4$ & 0.205 & 0.321 & 0.767 \\
\hline $\mathrm{CD} 3+\mathrm{CD} 19+$ & B cell & $15.4 \pm 2.0$ & $17.0 \pm 1.2$ & $17.3 \pm 0.9$ & 0.527 & 0.810 & 0.600 \\
\hline CD4+CD25+ & & $16.8 \pm 2.3$ & $17.0 \pm 1.4$ & $11.4 \pm 0.9$ & 0.051 & $<0.001^{*}$ & 0.674 \\
\hline $\mathrm{CD} 4+\mathrm{CD} 45 \mathrm{RO}+$ & Memory T & $28.0 \pm 2.4$ & $27.1 \pm 1.6$ & $23.0 \pm 0.9$ & 0.039 & $0.007^{*}$ & 0.810 \\
\hline CD4+CD45RA+ & Naïve $T$ & $22.9 \pm 2.7$ & $26.9 \pm 2.0$ & $25.8 \pm 1.5$ & 0.427 & 0.656 & 0.289 \\
\hline $\mathrm{CD} 4+\mathrm{CXCR3+}$ & Th1 & $23.9 \pm 3.5$ & $24.9 \pm 2.4$ & $19.6 \pm 1.9$ & 0.188 & 0.039 & 0.722 \\
\hline CD4+CCR5+ & Th1 & $0.7 \pm 0.2$ & $1.0 \pm 0.3$ & $1.4 \pm 0.3$ & 0.112 & 0.062 & 0.730 \\
\hline CD4+CCR4+ & Th2 & $25.2 \pm 2.1$ & $26.9 \pm 1.9$ & $26.4 \pm 1.4$ & 0.602 & 0.785 & 0.470 \\
\hline $\mathrm{CD} 4+\mathrm{CCR} 3+$ & Th2 & $1.1 \pm 0.2$ & $0.9 \pm 0.2$ & $1.8 \pm 0.2$ & 0.022 & $0.001^{*}$ & 0.272 \\
\hline $\mathrm{CD} 8+\mathrm{CXCR3}+$ & $\mathrm{Tc} 1$ & $21.1 \pm 4.1$ & $18.3 \pm 1.0$ & $15.4 \pm 1.9$ & 0.183 & 0.020 & 0.844 \\
\hline CD8+CCR4+ & $\mathrm{Tc2}$ & $9.5 \pm 2.4$ & $6.9 \pm 0.7$ & $9.6 \pm 0.9$ & 0.355 & 0.017 & 0.952 \\
\hline $\mathrm{CD} 4+\mathrm{CXCR3}+/ \mathrm{CD} 4+\mathrm{CCR} 4+$ & Th1/2 & $1.0 \pm 0.1$ & $1.0 \pm 0.1$ & $0.8 \pm 0.1$ & 0.122 & 0.023 & 0.908 \\
\hline $\mathrm{CD} 4+\mathrm{CXCR} 3+/ \mathrm{CD} 4+\mathrm{CCR} 3+$ & Th1/2 & $31.4 \pm 9.4$ & $23.1 \pm 2.4$ & $13.7 \pm 1.9$ & 0.035 & $0.007^{*}$ & 0.966 \\
\hline $\mathrm{CD} 4+\mathrm{CCR} 5+/ \mathrm{CD} 4+\mathrm{CCR} 4+$ & Th1/2 & $0.03 \pm 0.01$ & $0.03 \pm 0.01$ & $0.06 \pm 0.01$ & 0.093 & 0.041 & 0.646 \\
\hline $\mathrm{CD} 4+\mathrm{CCR} 5+/ \mathrm{CD} 4+\mathrm{CCR} 3+$ & Th1/2 & $0.7 \pm 0.2$ & $1.2 \pm 0.3$ & $0.8 \pm 0.1$ & 0.520 & 0.754 & 0.453 \\
\hline $\mathrm{CD} 8+\mathrm{CXCR3}+/ \mathrm{CD} 8+\mathrm{CCR} 4+$ & $\mathrm{Tc} 1 / 2$ & $3.4 \pm 0.6$ & $3.4 \pm 0.5$ & $2.0 \pm 0.3$ & 0.056 & $<0.001^{*}$ & 0.738 \\
\hline
\end{tabular}

Values indicate mean \pm standard error, PB: peripheral blood, NMO: neuromyelitis optica, MS: multiple sclerosis, HC: healthy control, Th: helper Tcell, Ti: inducer T, Ts: suppressor T, Tc: cytotoxic T, CCR: CC chemokine receptor, CXCR: CXC chemokine receptor. *Statistically significantly even after multiple comparison adjustment.

decreased percentages of $\mathrm{CD} 4^{+} \mathrm{CXCR} 3^{+}$Th1 cells $(P=$ $0.038)$ and $\mathrm{CD} 8^{+} \mathrm{CXCR} 3^{+} \mathrm{Tc} 1$ cells $(P=0.023)$ at the remission phase in all 5 MS patients (Figure 1). None of the lymphocyte subsets were correlated with clinical parameters such as EDSS, disease duration or antiAQP4 antibody titre.

\section{Discussion}

In this study, we analysed the expression of chemokine receptors on circulating PBL during relapse in NMO and MS patients and compare it with that of HC. We confirmed the dominance of the Th1- and Tc1-related chemokine receptors in MS patients; however, no remarkable differences were observed between NMO and $\mathrm{HC}$ patients.

Th1 and Th2 subsets of lymphocytes can be characterised by their expression of chemokine receptors. CXCR3 and CCR5 are associated with a Th1 phenotype, whereas CCR3 and CCR4 are expressed preferentially on activated Th2 cells [15]. Several studies have reported Th1 dominance over the Th2 response associated with chemokine receptors in MS, increased percentages of $\mathrm{T}$ cells expressing CXCR3 and CCR5 chemokine receptors on PBL and cerebrospinal fluid (CSF) in the active phase of MS and the identification of $\mathrm{CXCR} 3^{+}$and $\mathrm{CCR} 5^{+} \mathrm{T}$ cells in active demyelinating MS brain lesions [2,3]. Th1 dominance over the Th2 response is also indicated by decreased expression of the chemokine receptor CCR4 on blood T cells and brain tissue $[4,5]$. The results of our study indicates higher expression of Th1-associated chemokine receptors $\mathrm{CD} 4^{+} \mathrm{CXCR}^{+}$on peripheral $\mathrm{T}$ cells and lower expression of Th2-associated chemokine

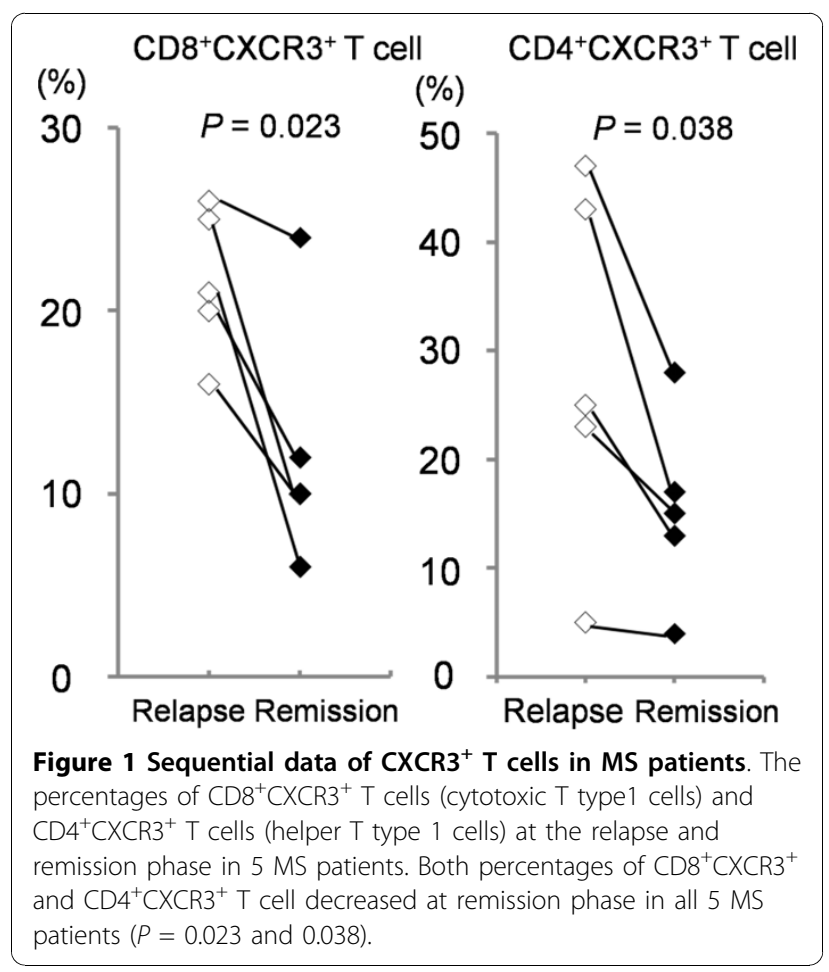


receptors such as $\mathrm{CD} 4{ }^{+} \mathrm{CCR} 3^{+}$in $\mathrm{MS}$ patients than in $\mathrm{HC}$, which is in accordance with the results of the abovementioned reports. Ratios of $\mathrm{CD} 4^{+} \mathrm{CXCR} 3^{+} / \mathrm{CD} 4^{+} \mathrm{CCR} 4^{+}$ and $\mathrm{CD}_{4}{ }^{+} \mathrm{CXCR} 3^{+} / \mathrm{CD} 4^{+} \mathrm{CCR} 3^{+}$were higher in $\mathrm{MS}$ patients than $\mathrm{HC}$, which also indicates Th1 dominance in balancing Th1/Th2 responses. Furthermore, we confirmed higher percentages of peripheral $\mathrm{CD} 4{ }^{+} \mathrm{CD} 25^{+}$ (regulatory or activated $\mathrm{T}$ cells) and $\mathrm{CD} 4{ }^{+} \mathrm{CD} 45 \mathrm{RO}^{+} \mathrm{T}$ cells (memory $\mathrm{T}$ cells) in MS patients than in $\mathrm{HC}$, which is in accordance with previous studies [16,17].

Our results estimated that the ratios of $\mathrm{CD}^{+} \mathrm{CXCR}^{+} /$ $\mathrm{CD} 8^{+} \mathrm{CCR} 4^{+}$, indicating $\mathrm{Tc} 1 / \mathrm{Tc} 2$, were significantly higher in MS patients than in HC. In addition, the percentage of $\mathrm{CD}^{+}{ }^{+} \mathrm{CXCR}^{+}{ }^{+}$and $\mathrm{CD}^{+}{ }^{+} \mathrm{CXCR} 3^{+} \mathrm{T}$ cells was correlated with disease activity in MS. The roles and functions of chemokine receptors on $\mathrm{CD} 8^{+} \mathrm{T}$ cells remain to be elucidated. $\mathrm{CD}^{+} \mathrm{CXCR}^{+} \mathrm{T}$ cells are associated with migration and differentiation of memory $\mathrm{T}$ cells [18] and also have a similar function as regulatory $\mathrm{T}$ cells (Treg) [19]. Our results indicate Tc1 dominance over Tc2 in MS, which may reflect the abnormality of Treg in MS.

To the best of our knowledge, no studies have reported the expression of chemokine receptors on PBL in NMO patients. A few studies have investigated chemokine levels in NMO, in which CXCL10/IP-10 and CCL17/TARC levels were significantly elevated in NMO patients [20] and CXCL-8/IL-8, CCL4/MIP- $1 \beta$ and CCL2/MCP-1 levels showed significant elevation in opticospinal MS patients (part of them are considered $\mathrm{NMO}$ ) compared with normal subjects [10].

Recent studies have shown that anti-AQP4 antibody and complements play a critical role of in the pathogenesis of NMO [21]. Thus, we expected the up-regulated expression of Th2-related chemokine receptors in NMO; however, no remarkable deviation in the Th1/ Th2 balance was observed in this study. Recent studies have revealed that Th17-related cytokines and chemokines play a dominant role in the pathogenesis of NMO from elevated protein levels of IL-17 and IL-8 in the CSF of opticospinal MS patients [10] and IL-6 in the CSF of NMO patients [11]. Th17 cells belong to a distinct lineage of Th1 and Th2 cells, which are responsible for organ-specific autoimmune diseases. Although the association between Th17 cells and NMO remains unclear, Th17 related-responses may be more important than Th1-and Th2-related responses in NMO pathogenesis. Hence, no remarkable changes might be seen in the Th1/Th2-related chemokine receptors on peripheral $\mathrm{T}$ cells. However, our study has a limitation because the subject was chemokine receptors on only PBL, and not on CSF, and thus we were unable elucidate the complete Th1/Th2 balance in the pathogenesis of MS and NMO.

In this study, some patients received oral prednisolone treatment. It has been reported that high-dose intravenous methylprednisolone reduced $\mathrm{CD}^{+} \mathrm{CXCR} 3^{+}$ Th1 cells [17] and CCR $5^{+}$Th1 cells in MS patients [22]. Hence, it can be suggested that steroid treatment affected the expression of chemokine receptors in this study. However, only one (4\%) patient with MS and three (25\%) with NMO received oral prednisolone at sampling PBL, and no statistical difference was found between the percentage of patients treated with steroid in NMO and MS. We hypothesise that steroid treatment had a relatively small effect on the results. Meanwhile, higher WBC counts and lower lymphocyte percentages in NMO and MS patients were possibly affected by immunomodulating therapy.

\section{Conclusions}

In conclusion, we have identified several differences, such as Th1 and Tc1 dominance and the association between $\mathrm{CXCR}^{+}$(Th1 and Tc1) and disease activity in $T$ cell subsets on PBL, in MS patients compared with $\mathrm{HC}$, but these differences did not appear in NMO patients. We cannot determine characteristic lymphocyte subsets on PBL involved in the pathophysiology of NMO. Although further studies will be required to determine the immunological features of NMO, these differences in PBL could be based on immunological differences between NMO and MS.

\section{Abbreviations}

MS: multiple sclerosis; NMO: neuromyelitis optica; HC: healthy control; AQP4: anti-aquaporin-4; EDSS: expanded disability status scale; PBL: peripheral blood lymphocyte; WBC: white blood cell; helper T: Th; cytotoxic T: TC; Treg: regulatory T; CCR: CC chemokine receptor; CXCR: CXC chemokine receptor; CSF: cerebrospinal fluid;

\section{Acknowledgements}

We would like to thank Toshiko Kajiwara, Akiyoshi Kodama and Masayuki Ohyama, Division of Clinical Laboratory Medicine, Chiba University Hospital for their special technical support.

\section{Author details}

'Department of Neurology Graduate School of Medicine, Chiba University, Chiba, Japan. ${ }^{2}$ Department of Molecular Diagnosis, Graduate School of Medicine, Chiba University, Chiba, Japan.

\section{Authors' contributions}

$\mathrm{AU}$ drafted the manuscript and carried out the statistical analysis. MM diagnosed MS and NMO patients, collected blood samples and provided other information of the patients. SH and FN participated in the design of the study. MM and SK critically reviewed the manuscript. All authors have read and approved the final manuscript.

\section{Competing interests}

The authors declare that they have no competing interests.

Received: 26 August 2010 Accepted: 11 November 2010 Published: 11 November 2010

\section{References}

1. Luster AD: Chemokines-chemotactic cytokines that mediate inflammation. N Engl J Med 1998, 338:436-45. 
2. Sørensen TL, Tani M, Jensen J, Pierce V, Lucchinetti C, Folcik VA, Qin S, Rottman J, Sellebjerg F, Strieter RM, Frederiksen JL, Ransohoff RM: Expression of specific chemokines and chemokine receptors in the central nervous system of multiple sclerosis patients. J Clin Invest 1999, 103:807-15.

3. Balashov KE, Rottman JB, Weiner HL, Hancock WW: CCR5(+) and CXCR3(+) $T$ cells are increased in multiple sclerosis and their ligands MIP-1alpha and IP-10 are expressed in demyelinating brain lesions. Proc Natl Acad Sci USA 1999, 96:6873-8.

4. Misu T, Onodera H, Fujihara K, Matsushima K, Yoshie O, Okita N, Takase S, Itoyama Y: Chemokine receptor expression on T cells in blood and cerebrospinal fluid at relapse and remission of multiple sclerosis: imbalance of Th1/Th2-associated chemokine signaling. J Neuroimmunol 2001, 114:207-12.

5. Imai T, Nagira M, Takagi S, Kakizaki M, Nishimura M, Wang J, Gray PW, Matsushima K, yoshie O: Selective recruitment of CCR4-bearing Th2 cells toward antigen-presenting cells by the CC chemokines thymus and activation-regulated chemokine and macrophage-derived chemokine. Int Immunol 1999, 11:81-8.

6. Wingerchuk DM, Lennon VA, Pittock SJ, Lucchinetti CF, Weinshenker BG: Revised diagnostic criteria for neuromyelitis optica. Neurology 2006, 66:1485-9.

7. Lennon VA, Kryzer TJ, Pittock SJ, Verkman AS, Hinson SR: IgG marker of optic-spinal multiple sclerosis binds to the aquaporin- 4 water channel. $J$ Exp Med 2005, 202:473-7.

8. Roemer SF, Parisi JE, Lennon VA, Benarroch EE, Lassmann H, Bruck W, Mandler RN, Weinshenker BG, Pittock SJ, Wingerchuk DM, Lucchinetti CF: Pattern-specific loss of aquaporin-4 immunoreactivity distinguishes neuromyelitis optica from multiple sclerosis. Brain 2007, 130:1194-205.

9. Ito S, Mori M, Makino T, Hayakawa S, Kuwabara S: "Cloud-like enhancement" is a magnetic resonance imaging abnormality specific to neuromyelitis optica. Ann Neurol 2009, 66:425-8.

10. Ishizu T, Osoegawa M, Mei FJ, Kikuchi H, Tanaka M, Takakura Y, Minohara M, Murai H, Mihara F, Taniwaki T, Kira J: Intrathecal activation of the IL-17/IL-8 axis in opticospinal multiple sclerosis. Brain 2005, 128:988-1002.

11. Uzawa A, Mori M, Ito M, Uchida T, Hayakawa S, Masuda S, Kuwabara S: Markedly increased CSF interleukin-6 levels in neuromyelitis optica, but not in multiple sclerosis. J Neurol 2009, 256:2082-4.

12. Uzawa A, Mori M, Hayakawa S, Masuda S, Kuwabara S: Different responses to interferon beta-1b treatment in patients with neuromyelitis optica and multiple sclerosis. Eur J Neurol 2010, 17:672-6.

13. Hayakawa S, Mori M, Okuta A, Kamegawa A, Fujiyoshi Y, Mitsuoka K, Ishibashi K, Sasaki S, Hattori T, Kuwabara S: Neuromyelitis optica and antiaquaporin-4 antibodies measured by an enzyme-linked immunosorbent assay. J Neuroimmunol 2008, 196:181-7.

14. McDonald WI, Compston A, Edan G, Goodkin D, Hartung HP, Lublin FD, McFarland HF, Paty DW, Polman CH, Reingold SC, Sandberg-Wollheim M, Sibley W, Thompson A, van den Noort S, Weinshenker BY, Wolinsky JS: Recommended diagnostic criteria for multiple sclerosis: guidelines from the International Panel on the diagnosis of multiple sclerosis. Ann Neurol 2001, 50:121-7.

15. Bonecchi R, Bianchi G, Bordignon PP, D'Ambrosio D, Lang R, Borsatti A, Sozzani S, Allavena P, Gray PA, Mantovani A, Sinigaglia F: Differential expression of chemokine receptors and chemotactic responsiveness of type 1 T helper cells (Th1s) and Th2s. J Exp Med 1998, 187:129-34.

16. Wu XM, Osoegawa M, Yamasaki K, Kawano Y, Ochi H, Horiuchi I, Minohara M, Ohyagi Y, Yamada T, Kira Jl: Flow cytometric differentiation of Asian and Western types of multiple sclerosis, HTLV-1-associated myelopathy/tropical spastic paraparesis (HAM/TSP) and hyperlgEaemic myelitis by analyses of memory CD4 positive T cell subsets and NK cell subsets. J Neurol Sci 2000, 177:24-31.

17. Wang HY, Matsui M, Araya S, Onai N, Matsushima K, Saida T: Immune parameters associated with early treatment effects of high-dose intravenous methylprednisolone in multiple sclerosis. J Neurol Sci 2003, 216:61-6.

18. Kobayashi N, Kondo T, Takata H, Yokota S, Takiguchi M: Functional and phenotypic analysis of human memory CD8+ T cells expressing CXCR3 J Leukoc Biol 2006, 80:320-9.

19. Shi Z, Okuno Y, Rifa'i M, Endharti AT, Akane K, Isobe K, Suzuki H: Human CD8+CXCR3+ T cells have the same function as murine CD8+CD122+ Treg. Eur J Immunol 2009, 39:2106-19.
20. Narikawa K, Misu T, Fujihara K, Nakashima I, Sato S, Itoyama Y: CSF chemokine levels in relapsing neuromyelitis optica and multiple sclerosis. J Neuroimmunol 2004, 149:182-6.

21. Saadoun $S$, Waters $P$, Bell BA, Vincent A, Verkman AS, Papadopoulos MC: Intra-cerebral injection of neuromyelitis optica immunoglobulin $\mathrm{G}$ and human complement produces neuromyelitis optica lesions in mice. Brain 2010, 133:349-61.

22. Elovaara I, Kuusisto $H$, Paalavuo R, Särkijärvi S, Lehtimäki T, Huhtala $H$, Vilpo J: Effect of high-dose methylprednisolone treatment on CCR5 expression on blood cells in MS exacerbation. Acta Neurol Scand 2006, 113:163-6.

\section{Pre-publication history}

The pre-publication history for this paper can be accessed here: http://www.biomedcentral.com/1471-2377/10/113/prepub

doi:10.1186/1471-2377-10-113

Cite this article as: Uzawa et al:: Expression of chemokine receptors on peripheral blood lymphocytes in multiple sclerosis and neuromyelitis optica. BMC Neurology 2010 10:113.

\section{Submit your next manuscript to BioMed Central and take full advantage of:}

- Convenient online submission

- Thorough peer review

- No space constraints or color figure charges

- Immediate publication on acceptance

- Inclusion in PubMed, CAS, Scopus and Google Scholar

- Research which is freely available for redistribution

Submit your manuscript at www.biomedcentral.com/submit
C Biomed Central 